\title{
REFLECTIONS ON FIELDWORK
}

Reflecting the Refuge Crisis: On the object of high-visibility reflection vests in humanitarian refugee corridors to the European Union

\section{IGNACIO FRADEJAS-GARCÍA}
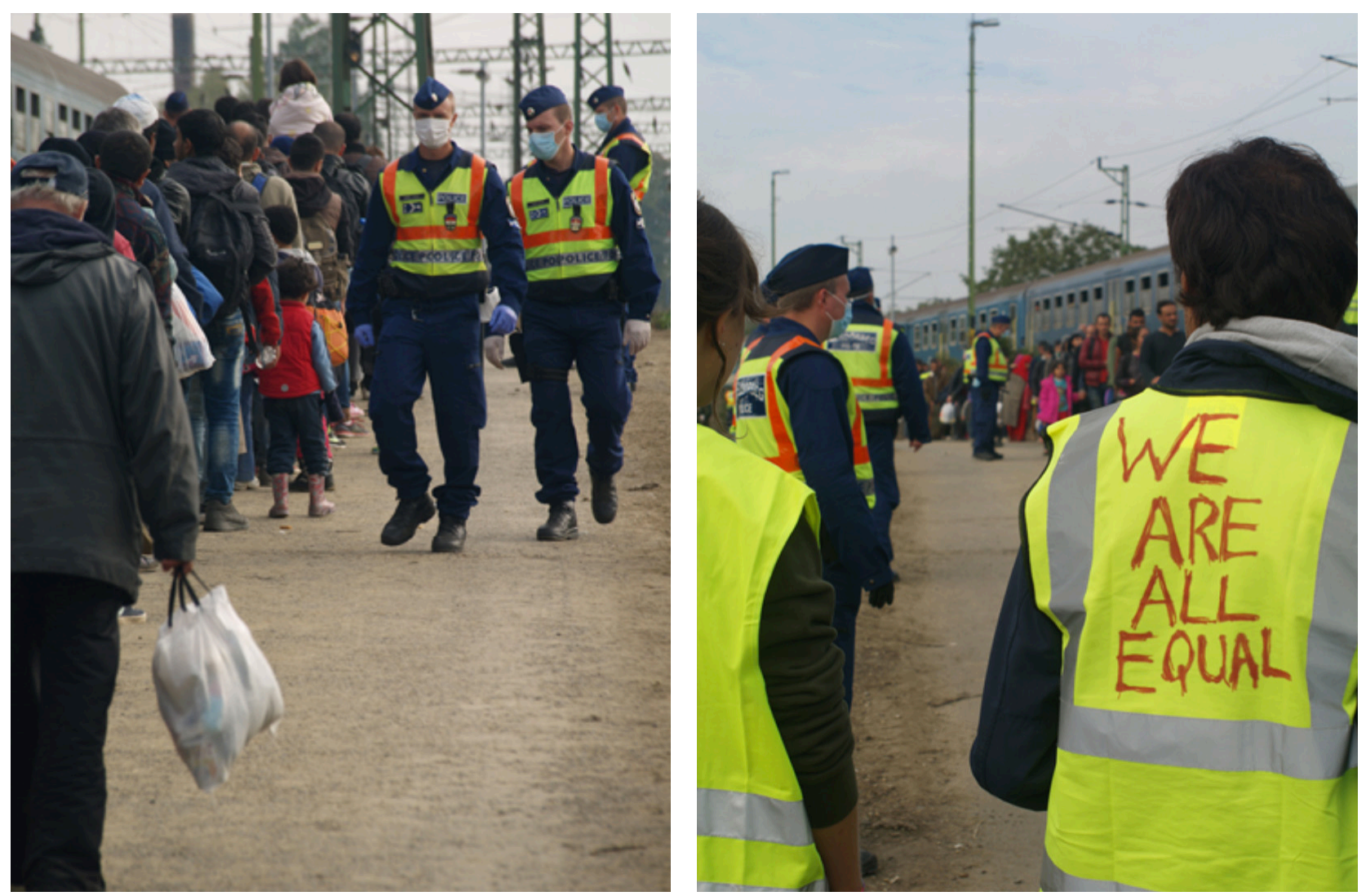

6 October 2015, Croatia-Hungary border. Police officers (left) and volunteers (right) organize and help, respectively, a group of thousand refugees getting on a train from Hungary to Austria.

All photos () Ignacio Fradejas-García

This work is licensed under the Creative Commons Attribution-NonCommercial-ShareAlike 4.0 International License | (C) Ignacio Fradejas-García. ISSN 2050-778X (Online). DOI: https://doi.org// 0.22 I8/unfamiliar. v7il.1892 


\title{
Reflecting the Refuge Crisis: On the object of high-visibility reflection vests in humanitarian refugee corridors to the European Union
}

\author{
IGNACIO FRADEJAS-GARCÍA
}

Visibility is the state of something that can be observed; invisibility, in contrast, is the non-observable. Signalling both status and role, high-visibility reflection vests are used by various professions such as police officers, security staff, construction workers, gardeners, transportation workers, volunteers or social workers. This inexpensive, easy to use artefact allows their bodies to become visible. The presence of a reflection vest signals power relationships, but also other working relations, or acts as a sign of warning and danger. Furthermore, the reflection vest has another capacity: it acts as an intrinsic artefact to the organisation of movement. A function that I witnessed in the autumn of 2015 when documenting the journey of a group of people on the move from the Turkish-Syrian border until Germany. Their goal was to seek refuge in the European Union. The field-research was conducted as part of my PhD project in Social Anthropology, analysing the humanitarian response to the Syrian crisis. The following text, however, looks closer at highvisibility-reflective-vests, reflecting on aspects of their function as objects of visibility and differentiation along the route through the Balkans into Europe.

On this journey I witnessed the power of different reflection vests. Reflection vests were ever-present at border crossings or refugee centres. Yellow, blue, red...sending out several messages through their various logos, words, and sentences: PRESS, Red Cross, Caritas, translator Arab-German or Police. All in different languages, typographies and graphics, clarifying the power invested in the person wearing the vest.

The border-crossing experience between Croatia and Hungary is used as example through the following text: I joined a group of refugees when they got off the train on the Croatian side of the border with Hungary. We were quickly guided onwards, following the instructions of different local people with reflection vests: Croatian policer officers, railway workers, ambulance personnel, Red Cross volunteers. Finally, we were met by militarised police officers on the Hungarian side, also wearing high-visibility reflection vests, concealing their camouflage suits for the occasion.

The long queue of refugees continued across a foot-bridge before being guided through a door in a high and long razor-wire-fence marking the national border between Croatia and Hungary. A translator with a yellow vest explained in Arabic through a megaphone that the humanitarian corridor was still open, and that all the refugees in the group were to take a free train across Hungary until the Austrian border. No identification was required; the entire group was socially invisible.

Before the refugees got on the new train in this new country, a group of volunteers, also wearing reflection vests, humanized the place with some words of welcome and good-hearted greetings. I stepped out of the group to take some photos one of which featured a volunteer with the words "WE ARE ALL EQUAL" written on his vest. As always I was trying to make sure that the refugees visible in the picture were out of focus, protecting their invisible social status by making them unrecognisable.

Since the volunteer was facing the refugees, the message of his vest remained hidden from them and only visible to the outside observer. When revisiting my photographs, in the light of thinking about the object of high-visibility reflection vests, I realized that this message could be interpreted in different ways: are all the people who dress in a reflection vest equal? Or are all the reflection vests equal? If everybody dresses in a reflection vest, will it not reflect any more? In this age of reproducibility (Benjamin 1936), individual written messages on these objects is one way - among others - to differentiate the object's reflections, singularizing a homogeneous object (Appadurai 1986), "constructing the objects as they construct the people" (Kopytoff 1986:90). 
After stepping out of the refugee group to take photographs it was not long until a police officer asked me what I was doing there. I did not belong; having left the group of refugees I was now the only one standing on the outside without a reflection vest that would have legitimated my presence. My camera had protected me for a few minutes, but I did not have a press vest. We anthropologists do not wear reflection vests! The police stopped me temporarily, but after their threats and my explanations, where I was made to assert my rights and status as a EU citizen, I was finally able to recover my privileged capacity to be (in)visible, and continue the journey.

During my travels with the refugees I quickly became aware of the advantages of checking the Refuge Volunteer Map ${ }^{1}$ daily. This was a website in google maps updated by anonymous volunteers about the situation on the borders, with helpful information about the local necessities to support the refugees passing by their localities. This collective effort has been helping refugees, migrants and other people on the move along the Balkans route from the beginning of the Syrian conflict. However, in 2015, with the so called 'refugee crisis' becoming a focus of the mass media, these volunteers were suddenly much more visible.

These very same volunteers complained about the criminalization of their humanitarian work and the lack of coordination, cooperation, and resources from States, the European Union, and the UNHCR - the United Nations High Commissioner for Refugees. One change resulting from this newfound visibility was that volunteers were forced by the police to identify themselves. Hence, they had started to wear reflection vests just like the police, while trying to highlight the practical and symbolic differentiation between 'us' and 'them', the heroes and the villains. Reflection vests are high-tech objects of our time, its high visibility signalling warning and attention. A future observer will also analyse, read and interpret their inscriptions, logos, writings and labels, helping to categorize the function, power, and reflection of the vest, and what individual or group was wearing it.

The newfound visibility among the volunteers, aided by the artefact of the high-visibility reflection vest, the very same signalling device used by state agencies of control that they try to subvert, was appropriated into something positive. Used by both volunteers and state agencies, the reflection vests, and its high visibility characteristic, have become a central object and tool of communication that is part of demarking a route and humanitarian corridor to peace and refuge in Germany or the European Union. Be it good or bad, reflection vests help frame a path across hostile lands and borders, through countries where governments are not welcoming refugees, or positive towards the routes existence. Nevertheless, the temporarily indifferentiable, and hence invisible, mass of refugees, migrants and people on the move, are vulnerable to the threat of visibility and exclusion as they negotiate a route guided by highly-visible-reflection-vest-carrying-officials controlling the regime-of-mobility of the European Union fortress.

\section{References}

Appadurai, A. (1986) 'Introduction: commodities and the politics of value'. Pp. 3-63 in A. Appadurai (ed.) The Social Life of Things: Commodities in Cultural Perspective. Cambridge: Cambridge University Press.

Benjamin, W. (1936) The Work of Art in the Age of Its Technological Reproducibility, and Other Writings on Media. Cambridge: Harvard University Press.

Kopytoff, I. (1986) 'The Cultural Biography of Things: Commoditization as a Process'. Pp. 64-91 in A. Appadurai (ed.) The Social Life of Things: Commodities in Cultural Perspective. Cambridge: Cambridge University Press.

Ignacio Fradejas-García, Universitat Autònoma de Barcelona, Department of Social and Cultural Anthropology, Research Group on Fundamental and Oriented Anthropology (GRAFO)

1 [Online] https://www.google.com/maps/d/viewer?mid=1qH3FWHISW70aGQ_TUT_m43GfXgI\&hl=en_US\&ll=49 $.17826807143503 \% 2 \mathrm{C} 10.524329951074264 \& \mathrm{z}=4$ [Accessed 17 June 2017] 